This is the accepted version of the following article: American Hegemony or Global Governance? Competing Visions of International Security, International Studies Review, vol.7, no.4 (2005) 531-545, which has been published in final form at http://onlinelibrary.wiley.com/doi/10.1111/j.1468-2486.2005.00531.x/abstract

The printed article is also available through JSTOR.

\title{
American Hegemony or Global Governance? Competing Visions of International Security
}

\author{
ELKE KRAHMANN \\ University of Bristol
}

Since the 1990s, the concepts of global and security governance have emerged as new frameworks for the analysis of international relations. The proponents of these approaches have argued that we are witnessing a transformation of global politics through the simultaneous dynamics of integration and fragmentation. The result of these two dynamics is a shift away from the state as the primary authority and actor in international affairs, thus challenging the state-centric theoretical perspectives that have been developed during the Cold War. Although states retain a central role, the literature on global and security governance suggests that a growing number of international organizations and private actors, such as multinational corporations and non-governmental organizations, are taking on functions ranging from the making to the implementation of international policies (Rosenau and Czempiel 1992; Finkelstein 1995). Moreover, in addition to sectors such as those involving international finance, economics, and the environment (Young 2000; Hall and Biersteker 2002), the proponents of the governance concept find that the fragmentation of policymaking capabilities and authority among state and non-state actors can also be increasingly observed in international security arena. In 1995, the Commission on Global Governance (1995: 99) observed:

The breakdown of the bipolar cold war system means that responses to security crises - both with preventive efforts and beyond them - have to come from a wider group of nations and organizations than before. The United Nations, particularly the Security Council, has the principal responsibility. But regional bodies and a wide range of civil society organization are now in a position to play useful roles.

Nearly ten years later, the concepts of global and security governance have increasingly become popular in the study of international security (Axworth 2001; Duffield 2001; Croft et al. 2004). This popularity rests on the argument that subnational and transnational threats such as civil war, ethnic cleansing, transnational crime, and terrorism are some of today's key security concerns and require a broadened definition of security that includes people as well as states (Krause and Williams 1997; (Buzan, Waever, and de Wilde 1998). Moreover, as contemporary security threats move away from or beyond the nationstate, a growing number of scholars have observed that non-state actors are taking on crucial roles in the provision of security, ranging from humanitarian aid to military services (Gordenker and Weiss 1996; Krahmann 2005).

The conflict in the former Yugoslavia soon after the end of the Cold War appeared to illustrate the simultaneous fragmenting and integrating tendencies of the new international security environment. Not only was the conflict caused by the internal break-up of a state, the international response to the war was also characterized by a multiplicity of actors including major powers, such as the United 
States, Britain, and France; international organizations, such as NATO, the United Nations, and the European Union; and non-state actors, such as the International Red Cross, national and international charities, and private military companies (Minear, van Baarda, and Sommers 2000; ICRC 2001;Cooley and Ron 2002).

Moreover, the US government seemed to support the emergence of a new system of global governance after its rise to the status of the "only surviving superpower." Both Presidents George H. W. Bush and Bill Clinton seemed to emphasize the need for international collaboration and the use of international organizations in order to promote a "new world order" which was to replace the realist international system of bipolarity and balance-of-power that had dominated the Cold War era (Dumbrell 2002:296; Jervis 2003: 83).

On the eve of the first war against Iraq on September 11, 1990, the first President George Bush declared before Congress: "The crisis in the Persian Gulf, as grave as it is, also offers a rare opportunity to move toward an historic period of cooperation. Out of these troubled times, our fifth objective - a new world order - can emerge." The authorization of the United Nations for the US-led intervention in Iraq was crucial for this new world order in which "nations recognize the shared responsibility for freedom and justice" and the UN would "perform as envisioned by its founders" (Bush, 2000). Bill Clinton's policy toward the former Yugoslavia was similarly characterized by a leadership which recognized the limitations of US strength; he worked long and hard to build an international coalition which would eventually support an American military intervention in 1995 (Jakobsen 1994; Gow 1997; Krahmann 2003a).

The events of September 11, 2001 and the security policies of the current Bush administration appear to have challenged this vision of a new world order based on global governance. Although the cause of the attack was terrorism, that is, a transnational security threat, subsequent American policy responses seem to have moved away from the view that contemporary security threats require concerted action among state and non-state actors. Conversely, the reaction of the US government appears to be more in line with traditional concepts of neorealist power politics than global governance. The interventions in Afghanistan and Iraq not only illustrate that transnational security threats can be dealt with within a state-centric framework, they also appear to confirm that at least superpowers can essentially do so unilaterally.

Accordingly, current academic debate appears to have turned away from exploring the nature of the concepts of global and security governance toward the question of whether we are witnessing the rise of US hegemony within a system which, despite all assertions to the contrary, has remained focused on nation-states and power politics (Kaldor 2003: 2). Observing the clash of these two competing perspectives on international security, the objectives of this essay are threefold. First, it seeks to examine the diverging theoretical assumptions underlying the concepts of hegemony and governance with regard to international security. Second, it outlines some of the competing hypotheses that have been proposed by these two theories regarding major power policies and the likelihood conflict among them. Third, it seeks to encourage further discussion and research by presenting an initial survey of the evidence in favor of either a hegemonic strategy by the United States and balancing or bandwagoning behavior by other major powers or the continuation of the emergence of security governance since September 11, 2001.

\section{Hegemony and Security}

In order to fully understand the questions whether we are witnessing the rise of American hegemony and how this will impact upon global security, it is necessary to define the concept of hegemony and indicate its place within international relations theory. This section 
proceeds to do so by distinguishing the notion of hegemony from other concepts such as imperialism and unipolarity. It then discusses the assumptions and hypotheses regarding international security linked to these concepts within the neorealist tradition, broadly conceived. This approach appears to be justified by the observation that although other approaches such as neo-Gramscianism (Cox 1987; Rupert 1995) have extensively discussed the concept of hegemony, neorealist propositions regarding unipolarity and balance of power have been at the center of the recent debate concerning US imperialism (Ikenberry 2002; Jervis 2003; Posen 2003).

\section{Unipolarity, Hegemony, and Imperialism}

The recent literature on US political and military pre-eminence is characterized by a confusing variety of terms and concepts, including unipolarity, primacy, hegemony, and imperialism (Agnew, 2003). Moreover, these terms have been combined or juxtaposed in multiple ways. Thus, varying authors distinguish between "non-hegemonic" and "hegemonic" unipolarity, between "benign" and "(neo)imperialist" hegemony, or between "benevolent" and, presumably, "evil" empires. Furthermore, there is no clear consensus as to which of these terms applies to the United States in the post-Cold War international environment. Only a systematic analysis can establish the differences between these concepts and their interpretation of American primacy. Specifically, it seems necessary to distinguish between three distinct, but interrelated, concepts: unipolarity, hegemony, and imperialism.

The concept of polarity has traditionally been defined as the relative distribution of capabilities within the global international system. It is a structural concept. In the bipolar system of the Cold War, polarity was characterized by the overwhelming political, military, and economic resources of the United States and the Soviet Union - the two "superpowers" - in relation to other states. Since 1990, the break-up of the Soviet Union has left the United States as the sole superpower and the only "pole" within the international system. It is, thus, widely accepted that we are currently in a unipolar system (Wilkinson 1999:141; Wohlforth 1999:7; Posen 2003:6). No other states, including Russia, the United Kingdom, France, and China, can compare to the United States in terms of military capabilities or political influence. ${ }^{1}$

The concept of hegemony is also typically defined in terms of the distribution of capabilities within the international system. However, unipolarity does not necessarily entail hegemony; nor can hegemony only be found in unipolar structures. What distinguishes hegemony from unipolarity appears to be a relational element. Hegemony can be defined as capabilities that are matched by influence over other states in the international system (Wilkinson 1999: 142). ${ }^{2}$ During the Cold War, that is, under bipolarity, hegemony was thus ascribed to the United States in relation to its allies within the North Atlantic Alliance or in Asia. However, in spite of its capabilities, during this time period the United States was not in a hegemonic position vis-à-vis the members of the Warsaw Pact. Under the conditions of unipolarity, the United States appears to have further expanded its hegemony, for instance with the enlargement of NATO. Yet, American hegemony is far from global with major powers such as Russia and China resisting its leadership.

The definition of imperialism, conversely, can be said to rest on policies in addition to capabilities and influence (Ikenberry 2002). Imperialism builds on

\footnotetext{
${ }^{1}$ Of course, different definitions and measures of state power abound in the literature, including such things as military expenditures, gross domestic product, population, geography, and political and cultural influence (for an overview, see Merritt and Zinnes 1989). Nevertheless, the United States today clearly surpasses other countries across most of these measures (see Mastanduno 1997:54).

${ }^{2}$ However, following Thomas Volgy and Lawrence Imwalle (1995: 823), this definition departs from David Wilkinson's in that it suggests that hegemony may be found in unipolar and bipolar as well as multipolar structures.
} 
unipolarity and hegemony because it suggests not only having the resources and power to shape international relations but also the willingness to do so and - if necessary - to do so coercively. John Agnew (2003: 876) argues that one difference between hegemony and empire is "its reliance, to some degree, on persuading or rewarding subordinates rather than immediately coercing them, although even empire... is never reliably achieved by purely coercive means." Moreover, imperialist powers seek to expand their influence and capabilities and to prevent other states from challenging their pre-eminence within the international system through conquests and interventions (Jervis 2003).

Based on this differentiation between unipolarity, hegemony, and imperialism, the diverging interpretations of the US position in international affairs since the early 1990s become explicable. The policy shift of the George W. Bush administration after September 11 may justifiably have transformed perceptions of the United States from that of a benign hegemon to a neo-imperialist power. In sum, the above suggests that although the condition of unipolarity remains unaltered, changes in influence and policies determine whether we are faced with non-hegemonic, hegemonic, or imperialist unipolarity (Wilkinson 1999).

\section{Hegemony in Neorealist Theories}

The second question that needs to be answered is where unipolarity, hegemony, and imperialism are located within international relations theory and how these concepts add to our understanding of security and conflict. The most extensive discussion of unipolarity and hegemony in relation to contemporary international security can be found within the neorealist tradition and, indeed, this tradition has most strongly influenced the recent debate over US global policy. It is, therefore, the body of literature on which this essay will focus, although other theories such as neo-Gramscian approaches also discuss the conditions and effects of hegemony.

Necessarily simplifying the variety of existing neorealist approaches, neorealism can be said to build on two main assumptions. The first assumption is that states are the key actors in international security (Waltz 1979). Historically, this premise rests on the state monopoly of the legitimate use of violence which was strengthened during the past century through the professionalization of national armed forces and national arms industries. Indeed, the Cold-War Fordist state can be seen as the prime embodiment of this principle in that it centralized not only the provision of national and international security, but also of other key public functions such as healthcare, education, and communication (Kaldor 2003: 4). The state became the central political authority to the near exclusion of others.

The second assumption is that the international system is anarchic and that states are the most dangerous threat to one another (Waltz 1979). This premise builds directly on the first since the monopoly of the legitimate use of violence within the state means that there is no overarching authority at the international level with sufficient power to enforce peaceful coexistence and cooperation. It also asserts that no other actors have military, economic, or political capabilities which can compare to or effectively threaten states. Interstate war and the stability of the international system, that is, the survival of states, are the central concerns of neorealist theory.

From these two assumptions it follows that in order to ensure their own security states have to deter other states from threatening or attacking them. Their ability to do so effectively rests on their national military, economic, and political capabilities. In addition, states can seek to enhance their power vis-à-vis other states by entering temporary alliances either to balance the primary powers, and thus threats, within the international system or to bandwagon with them in the hope that these powers will protect them from other states (Waltz 1979: 126f.). 
But what does neorealism say about unipolarity, hegemony, and imperialism? Traditionally, many neorealist authors have been very skeptical about the maintenance of international security and stability under unipolarity (Mearsheimer 1990; Layne 1993). In particular Kenneth Waltz (1993) has argued that unipolarity is inherently unstable because of the lack of balance of power within the international system. Other states will inevitably feel threatened by the dominance of a single superpower and will try to counter it. Michael Mastanduno (1997: 54) agrees:

Balance-of-power theory is very clear about the behavioral implications of unipolarity. States seek to balance power, and the preponderance of power in the hands of a single state will stimulate the rise of new great powers, and possibly coalitions of powers, determined to balance the dominant state.

Worse still, some neorealists conclude that "major or global wars may erupt as a consequence of such challenges to hegemonic control" (Volgy and Imwalle 1995: 824). The dominant power within the international system can do little to prevent these conflicts. According to David Wilkinson (1999:143), "[t]he mere fact of its preponderance guarantees the rapid rise of competing powers. ... Balance-of-power theory suggests further that efforts to preserve unipolarity are bound to be futile and likely to be counterproductive."

Other authors are less pessimistic about the prospects for international security in a unipolar world. They suggest that hegemonic unipolarity might be the key to preserving peace (Posen and Ross 1996/1997: 32). Specifically, they argue that a hegemonic power can use its resources to deter or appease challengers (Ikenberry 2003). The first strategy involves maintaining or expanding its military and political preponderance because a greater capability gap between the hegemon and any potential challenger is more likely to discourage competitors. The second strategy involves the hegemon's use of its political influence to create international institutions which benefit its allies and the international order (Cronin 2001: 104). The ability of its allies and other states to free-ride on the advantages of these institutions will decrease their incentives to oppose the hegemon (Kagan 1998:26; Jervis 2003).

However, whereas a hegemonic strategy can enhance stability under unipolarity, an imperialist strategy threatens it. Thus, G. John Ikenberry (2003) writes:

My hypothesis is that the greater the United States tilts toward liberal hegemony, the greater the incentives these states will have to engage in cooperative behavior with the United States. The greater the United States tilts toward imperial hegemony, the more incentives states will have to resist or move away from the United States.

According to this line of thinking an imperialist strategy endangers peace for two main reasons. First, it increases threat perception among enemies as well as allies. Since the imperialist power is not only capable, but also willing to use its resources to actively prevent any would-be challengers from arising, no state can feel secure (Huntington 1999). Even cooperation with the imperialist power might not be sufficient to avert its interference because distrust is an inherent feature in the international system. In fact, cooperation with the imperialist power might strengthen its position and further exacerbate the threat. Second, the imperialist power is less willing to appease allies through multilateral cooperation or support for international institutions. Since the imperial power has the capabilities to implement its security policies unilaterally, it believes that cooperation can only delay or distract from its national interest (Cronin 2001: 104; Wallace 2002: 105).

In sum, neorealist approaches appear to propose three hypotheses with regard to security under the conditions of non-hegemonic, hegemonic, and imperialist unipolarity. First, non-hegemonic unipolarity is unstable and can lead to major interstate wars as new powers arise to challenge the sole superpower. Second, 
hegemonic unipolarity is more stable in that it might at least avoid interstate wars between the hegemon and allied countries. It cannot, however, prevent new threats from emerging among non-allied major powers. Third, imperialist hegemony is the least stable because it increases threat perceptions among allies as well as enemies and encourages counterbalancing policies.

\section{Global Security Governance}

The concept of governance has only recently been developed and applied to the study of international security. This section analyzes the main characteristics of the concept before discussing the assumptions and propositions which may be derived from it for the making and implementation of contemporary security policies.

\section{Global Governance}

Since the 1990s, the concept of global governance has been characterized by a variety of definitions and uses. However, in recent years there appears to have been an increasing convergence of meaning. According to this common understanding, the shift from "government" to "governance" denotes the increasing fragmentation and reintegration of political authority among state and non-state actors across levels of analysis (Czempiel 1992:250; Finkelstein 1995: 369; Gordenker and Weiss, 1999: 17). Specifically, this transformation of political authority can be observed along seven dimensions: its geographical scope, its functional scope, the distribution of resources, interests, norms, decision making, and policy implementation (Krahmann 2003c). Geographical fragmentation and integration away from the state as the central unit specifically takes three forms: "downward" to local bodies, "upwards" to international organizations, and "sideways" to private and voluntary actors. Fragmentation and reintegration appear in the form of aligning national, regional, and global policymaking arrangements according to functional divisions. The changing distribution of resources can be observed in the redistribution of policymaking and implementation capabilities among state and non-state actors.

With regard to interests, the dual dynamics underlying the shift from government to governance can be found in the growing acceptance of the heterogeneous and sometimes conflicting nature of interests and the aim to ensure that each actor can pursue them as uninhibited by external regulation as possible. Consider in this regard that the underlying premise of government used to be that individual preferences can and should be subordinated to the common interest. Governance norms, too, appear to favor the trend away from the state in the form of limited national sovereignty, self-government, and the marketization of social relations. Finally, the emergence of governance is characterized by the horizontal differentiation of policymaking and implementation among state and non-state actors. As a consequence, decision making within governance typically proceeds through negotiation and the formal and informal acceptance of structural inequality, for instance through weighted voting procedures; policies are implemented in a decentralized fashion. In fact, policies are often self-enforced and compliance is frequently voluntary.

\section{Security Governance}

But how does global governance relate to our understanding of international security? Much of the literature on global governance has focused on areas such as the environment, trade, and finance. However, there are a growing number of authors who have suggested that the fragmentation and integration observed in other sectors increasingly also characterize international security. The origins and 
consequences of this development are grasped by the concept of "security governance" (Krahmann 2003b).

The suggestion that we are witnessing the emergence of security governance since the 1990s rests on several assumptions concerning the changing nature of contemporary international relations. ${ }^{3}$ These assumptions are strikingly different from the premises of neorealism. The first assumption is that states are no longer the single most important source of threat to international security. Other threats such as terrorism, crime, and proliferation have become "equally important" (Commission on Global Governance, 1995: 79; see also Rosenau 1992: 3; Tuathail, Herod, and Roberts 1998: 12; Thomas 2000:161162). As a consequence, the Commission on Global Governance (1995: 78) argues: "Global Security must be broadened from its traditional focus on the security of states to include the security of the people and the planet."

The changing perception of threat within global governance theory builds on data from a variety of sources, such as the Stockholm International Peace Research Institute (SIPRI) or the Heidelberger Institut für Internationale Konfliktforschung (HIIK), which show that while interstate war is declining in frequency, new intranational conflicts and transnational threats are on the rise. Moreover, these statistics reveal that the number and casualties from internal and transnational conflicts typically exceeds those of interstate wars in the contemporary security environment (SIPRI, 2003; HIIK, 2003).

The second assumption is that the complexity and internal or transnational nature of contemporary security threats are not only putting increasing strain upon state resources, states are also finding that the sovereignty-bound policymaking arrangements which have been developed over the past centuries are inadequate when it comes to addressing transnational security issues (Haass 1999). As a result, a growing number of international organizations and private actors have emerged in order to deal with security issues such as humanitarian aid, human rights monitoring, refugees, and military training and protection (Commission on Global Governance, 1995: 86; Minear, van Baarda, and Sommers 2000; Murphy, 2000: 795f.; Singer, 2003).

The third assumption is that state legitimacy is no longer based on the monopoly on the provision of national and international security, but increasingly the cost-efficient delivery of security (Camm 1996; Markusen 2003: 473; Pint et al. 2001). Resting on the rise of neoliberal norms in global governance, such as privatization and marketization (Tuathail, Harod, and Roberts 1998: 6-9), this assumption suggests that the replacement of "government" with "governance" is changing security policymaking in a more fundamental way.

Several interrelated hypotheses follow from these assumptions for security governance. First, the search for cost-efficient security governance encourages geographical and functional specialization among state and non-state actors in the provision of security. Second, due to the new threats and the fragmentation of resources and capabilities, states increasingly need to cooperate with other actors, including other states, international organizations, non-governmental organizations, and private firms in order to effectively provide for their national security and that of their citizens. At the same time, collaboration decreases the threat perception among states and the probability of interstate war. Third, alliances and balance-of-power politics are replaced by flexible "coalitions of the willing." These coalitions come together on the basis of strategies and arrangements that are the most cost-effective with respect to a particular security issue, but they are not considered a

\footnotetext{
${ }^{3}$ It should be noted here that theories of global and security governance do not question the utility of the neorealist perspective for the analysis of international security during the Cold War. However, they argue that the conditions which made international relations in the second half of the past century particularly amenable to neorealist analysis are progressively changing.
} 
threat. Key factors which influence cost-efficiency include agreement with other actors, their capabilities and expertise, and the closeness and relevance of a security problem. Conflicts in Europe, for instance, are dealt with by other coalitions and institutions than in Africa; humanitarian security problems by other sets of actors than terrorism. In fact, actors are likely to use multiple organizations or coalitions at the same time in order to get maximum benefit from the specific capabilities and remit of each.

The concept of security governance, thus, supports three key hypotheses with regard to contemporary security. First, geographical and functional specialization decreases the threat of interstate wars among states. Second, states progressively collaborate with other state and non-state actors in providing national and international security. Third, changing, but structurally neutral, "coalitions of the willing" are taking the place of stable, but antagonistic alliances.

\section{International Security Post-September 11}

Having clarified the theoretical assumptions and hypotheses linked to hegemony and security governance, this section presents a first-cut examination of US and major power policies since September 11 from both the neorealist and global governance perspectives. To do so, this section is divided into three parts. The first part discusses whether the policies of the United States since the terrorist attacks on the World Trade Center can be defined as non-hegemonic, hegemonic, or imperialist. The second part analyzes how America's allies and other major powers have responded to US strategy and whether their actions concur with the hypotheses of neorealism. The third part examines whether and to what degree US and major power policies over the past four years match the propositions of security governance. Obviously, such a first cut cannot provide a definitive assessment of the two perspectives. However, it helps to illustrate the two competing visions and suggests further potential research.

\section{US Strategy: Non-hegemonic, Hegemonic, or Imperialist?}

Based on the definitions of non-hegemonic, hegemonic, and imperialist unipolarity presented above, there appears to be a widespread perception that US security policy has undergone a fundamental shift under George W. Bush, in particular since the events of September 11 (Wallace 2002: 112; Rhodes 2003). Robert Jervis (2003:83) has written:

The United States today controls a greater share of world power than any other country since the emergence of the nation-state system. Nevertheless, recent U.S. presidents George H.W. Bush and Bill Clinton still cultivated allies and strove to maintain large coalitions. ... By contrast, the fundamental objective of the current Bush doctrine - which seeks to universalize U.S. values and defend preventively against new, non-traditional threats - is the establishment of U.S. hegemony, primacy or empire.

As was argued earlier, there are several elements to what might be considered US imperialism. There is considerable agreement that the current international system is unipolar with the United States as the pre-eminent power in terms of military, economic, and political capabilities. In his detailed review of US military power, Barry Posen (2003: 10) pointed out that that the United States produces 23 percent of the gross world product and that 3.5 percent of the American GNP is devoted to defense as compared to 2.3 percent in China, 3.8 percent in Russia, and 2.5 percent in the United Kingdom and France. In SIPRI's analysis of the fifteen main spenders on defense among states in 2002, the United States ranks first with US $\$ 335.7$ billion, followed by China with 
$\$ 142.9$ billion, India with $\$ 66.5$, Russia with $\$ 55.4$ and France with $\$ 36.8$ (rankings are in purchasing power parity according to SIPRI 2003).

Moreover, in addition to capabilities, the United States has significant influence in international relations, allowing it to pursue both hegemonic and imperialist policies. It is a dominant player in major international institutions such as the United Nations, NATO, the International Monetary Fund, and the World Bank (Cox 2002:65; Wallace 2002: 108); it has close bilateral and multilateral relations with major and minor powers such as the United Kingdom, Germany, Japan, and South Korea; and it has what Joseph Nye (2002) has called "soft power" which builds on the nation's prestige and reputation, its cultural and economic influence, and its diplomatic relations, putting it in a prime position for the generation of coalitions in international relations (Nye 2002; Wallace 2002: 118).

Finally, the current Bush administration has shown an increased willingness to use its power in a unilateral manner and has adopted a doctrine of pre-emptive intervention in order to prevent would-be challengers to its position as the pre-eminent power in the international system (Ikenberry, 2002; Wallerstein, 2002; Kaldor, 2003:13; Rhodes 2003:134). It is this element which appears to define US policy post-September 11 as imperialist. The shift from a hegemonic to an imperialist policy is specifically embodied in the National Security Strategy of the United States of America (Bush 2002: 29) which asserts:

We know from history that deterrence can fail; and we know from experience that some enemies cannot be deterred. ... Our forces will be strong enough to dissuade potential adversaries from pursuing a military build-up in hopes of surpassing, or equalling, the power of the United States.

With the war in Iraq the US government put its new strategic doctrine into practice. Backed up by faulty intelligence, the administration decided to intervene pre-emptively to stop Iraq from developing weapons of mass destruction which would endanger the current world order. The intervention showed all the signs of an imperialist strategy. Not only was it a pre-emptive attack on a sovereign country, but it was conducted without explicit United Nations authorization and against the protests of key American allies and other major powers, including Russia, China, France, and Germany. Moreover, unlike the first Gulf War, the military operation was conducted by the United States with limited support from the United Kingdom and other close allies rather than a major international coalition.

\section{Major Powers: Bandwagoning or Balancing?}

The findings post-September 11 concerning the response of both allied and non-allied major powers-which typically are identified as France, the United Kingdom, Germany, Japan, Russia, and China--to the imperialist security policies of the United States are contradictory. As Ikenberry (2003) observes:

Scholars of international relations tend to think about two basic strategies that are available to states as they confront a predominant state: balancing and bandwagoning. One is the classic strategy of counter-balancing alliance. The other is the strategy of appeasement and acquiescence. But today, strategies for coping with a pre-eminent America tend to fall in between these extremes.

Although neorealist theory suggests that the declared imperialist strategy of the United States should hasten balancing behaviour among allied and non-allied powers, most countries aligned themselves with the United States in its "war on terrorism" (Wallace 2002: 113). In fact, NATO's Article 5, which calls for the collective defense of any alliance member under threat, was invoked for the first time since 
its foundation when America's European allies unanimously declared their support for the United States and its subsequent intervention in Afghanistan (Black 2001).

Non-allied major powers such as Russia and China should have felt threatened by a US military operation in Central Asia, which these two powers have traditionally regarded as their backyard. However, they also appeared to bandwagon with America in the immediate aftermath of the 9/11 attacks (Gittings 2001). Russia contributed to the intervention in Afghanistan by providing the United States with intelligence, by approving US military bases in the former Soviet Republics of Uzbekistan and Kyrgyzstan, and by offering landing rights in Tajikistan (Nau 2002). Moreover, Russia supported the United States in spite of the fact that the Bush administration had just unilaterally renounced the Anti-Ballistic-Missile (ABM) Treaty and even though NATO expansion was progressing against Russia's will (Traynor 2001).

However, allied and non-allied major powers chose to balance the United States when the Bush administration identified Iraq as the next target in the "war on terrorism." France, Germany, Russia, and China in particular opposed a pre-emptive military intervention in Iraq and insisted that the United Nations inspection team should be given more time in order to establish the existence of a WMD programme. The four countries also threatened to veto the resolution in favor of an intervention which was proposed by the United States, the United Kingdom, and Spain in the United Nations Security Council (Younge at al. 2003). When the United States began air strikes on March 20, 2003, the four countries led international protests against the intervention with China calling for an "immediate halt to military actions against Iraq" (Henley et al. 2003).

The most surprising opposition to the US intervention in Iraq came from Turkey, traditionally a strong supporter of the United States within the Atlantic Alliance. Despite its close relations and an offer of $\$ 24$ billion in US grants and loans to compensate for the impact of the war, Turkey rejected a US request for access to military bases on its border with Iraq, thereby dealing a severe blow to US military plans. American strategists had hoped to be able to open a second front in northern Iraq by launching up to 62,000 troops from Turkish territory. In fact, much of this contingent was already waiting on US warships in the Mediterranean and had to be re-diverted to the Gulf (Guardian 2003a; Guardian 2003b; Smith 2003).

However, the balancing behavior of allied and non-allied countries over Iraq did not represent a general policy shift in response to a more imperialist United States. Instead extensive diplomatic efforts have been made to heal the relations between the United States and its allies in spite of continued differences of opinion regarding the intervention. Since the end of the war, most major powers have collaborated with the United States in the pacification of Iraq or have offered financial aid for the reconstruction effort (Sharrock 2003). A further concession to the United States has involved NATO's decision to help with the training of Iraqi security forces (Dombey 2004; NATO 2004).

\section{U.S. and Major Power Strategies: The Continuation of Security Governance}

An alternative vision of international security is presented by the notion of security governance. Specifically, this approach, as noted earlier, proposes three competing hypotheses to explain contemporary national and international security policies. First, it argues that states are increasingly differentiated by geographical and functional specialization in the provision of security. Second, it suggests that states progressively accept the need for collaboration with both state and non-state actors. Third, security governance proposes that the balance-of-power politics of the past century are being replaced by changing and flexible "coalitions of the willing." 
Accordingly, the policies of the United States and other major powers since September 11, 2001 can also be viewed in a different way. In particular, the concept of security governance highlights the complexity of contemporary interventions beyond the leadership of the United States. This includes evidence for an emerging functional and geographical division of labor among the state and non-state actors involved in the interventions in Afghanistan and Iraq. Although the initial military operation in Afghanistan was conducted by the United States and the United Kingdom, this perspective emphasizes that the subsequent peacekeeping mission has been conducted and led by a large number of countries with fewer offensive capabilities but growing experience in post-conflict reconstruction, such as Germany, the Netherlands, and Canada (see Bernstein 2003; Canada Department of National Defense 2005; NATO 2005). Similarly in Iraq, the United States fought the war, but more than thirty countries are contributing to peacekeeping in the region with nearly 27,000 troops.

Moreover, beyond the "war on terrorism," the geographical reach and interests of the United States are more limited than is implied by the term imperialism and much of the literature on "American imperialism." During the re-emergence of conflict in Liberia in 2004, a country which has close links to the United States, 2,300 American troops remained on ships stationed off the Liberian coast, while the Economic Community of West African States (ECOWAS) despatched a 3,250-strong peacekeeping force (Manhire 2003; Woollacott 2003). In fact, the Bush administration is currently attempting to strengthen African self-management of security issues such as terrorism and civil war. Initiatives to increase regional security governance in Africa include US support for a formal antiterrorism alliance between Morocco, Algeria, Tunisia, Chad, Niger, Senegal, Mauretania, and Mali (Whitmore 2004) as well as a multilateral African Standby Force of five brigades within the context of the African Union (Koch 2004).

In addition to encouraging functional and geographical specialization in security governance, the United States collaborates extensively with other state and non-state actors in the provision of international security, despite the unilateralist rhetoric of George W. Bush. Both in Afghanistan and Iraq, the United States sought a United Nations mandate and consulted with allied and non-allied countries in order to rally support for its interventions. Although these consultations did not succeed with regard Iraq, they nevertheless indicate the willingness to use global and regional governance organizations to deal with major international security issues. The United States has also been urging a greater role for NATO in the ongoing peacekeeping missions in both Afghanistan and Iraq in order to alleviate the strain on its own armed forces (Sciolino 2004). Moreover, although the United States clashed with allied and non-allied countries over its policies in Iraq, these disagreements did not precede military hostilities and seem very unlikely to lead to interstate conflict between the United States and the other major powers. As Ikenberry (2003) has argued:

It seems likely that the United States will not choose to go very far down a neo-imperial path--the costs are too great and it is ultimately not a sustainable grand strategic orientation for the United States. It seems also likely that the basic character of the order that exists between democratic great powers--Western Europe, the United States, and Japan--will persist even under conditions of unipolarity. That is, these countries will continue to inhabit a "security community" where the disputes between them will ultimately be settled peacefully.

Beyond these military operations, there is additional evidence for the reliance of the United States on the capabilities and resources of other actors. As has been pointed out above, both the interventions in Afghanistan and Iraq are drawing increasingly on the military personnel and financial aid of countries other than the United States. Financial aid was also offered by states such as Russia, China, France, 
and Germany, which had opposed the intervention. The current US budget deficit which has been fuelled by increased defense spending and the costs of the interventions further shows that even a superpower which accounts for 23 percent of the world gross domestic product cannot "go it alone" (Haass 1999; Shanker 2003; Graham 2004). Additional problems are created by an overstretch of the US armed forces which effectively prohibit any further major interventions until it is able to withdraw from Iraq.

Moreover, during its interventions, the United States has increasingly relied on private military capabilities to support and supplement its national armed forces. In particular, airlift and logistics are today provided by private companies rather than the military itself. And the current focus on the stabilization of both Afghanistan and Iraq requires extensive use of private contractors for internal and external security and reconstruction (Weisman and Reddy 2003). Halliburton's subsidiary, Kellogg, Brown, and Root, has already been used for these purposes in the former Yugoslavia and has recently received notoriety for overcharging the US military over supplies and services in Iraq (Spinner 2004).

Finally, there is empirical evidence supporting the hypothesis that hegemonic leadership within stable alliances or imperialist unilateralism are progressively replaced by coalitions of the willing. When NATO offered its support in Afghanistan, the United States and the United Kingdom chose not to make use of its decision-making structures (Dumbrell 2002). Only after the military operations had been concluded in Iraq and Afghanistan, NATO was considered as a potential contributor (Sciolino 2004). However, the refusal to use or work within the multilateral institutions of NATO is not considered a return to multipolarity, it rather seems part of a more flexible approach toward alliances and international institutions. According to this approach, alliances and international organizations are tools which can be used for particular purposes, such as peacekeeping, and in particular circumstances, such as with the agreement among its members. This explains why NATO has been used more extensively in Afghanistan than in Iraq where allies disagreed over the objectives of the operation. Crucially, since the United States and these other states continue to cooperate in other institutions, this flexibility does not entail any threat to it or to them.

\section{Conclusion}

This essay has presented two competing visions of contemporary international security: US hegemony and security governance. According to these perspectives we are either witnessing the return to classical balance of power politics in which the United States as the sole surviving superpower can impose hegemonic or imperialist policies upon other nations or the continuation of a new era of security governance which began after the end of the Cold War. In order to understand these two visions, this essay has attempted to clarify the concepts of hegemony and security governance and the hypotheses respectively linked to these two approaches. Moreover, it has sought to present a first-cut analysis of some of the evidence which might be brought forward in support of each theory. Necessarily the empirical evidence presented here has been limited. However, several preliminary conclusions can be drawn from this evidence that can serve as a starting point for further debate and research.

Specifically, the preceding analysis has illustrated why the policies of the United States since September 11 might not only be perceived as hegemonic, but also as imperialist within the context of neorealist theorizing. According to this view, the current unipolar international system has encouraged the United States to engage in policies designed to continue its pre-eminence and influence in global politics. Moreover, the doctrine of pre-emptive intervention and its application in Iraq appear to be confirming this interpretation. 
The policies of the major powers in response to Bush's "neoimperialist" strategy, however, are less clear when we consider the hypotheses advanced by neorealist authors. While the neorealist approach suggests that an imperialist strategy should hasten balancing behavior among allied as well as non-allied major powers, key states such as Russia, China, France, and Germany have so far alternated between supporting and opposing the United States on various issues.

In contrast, the emergence of security governance appears to explain the changing strategies of America's allies. It suggests that major powers, including the United States, are increasingly collaborating through flexible coalitions of the willing. Crucially, these flexible coalitions are not a new form of balance of power, but respond to differences in interests and capabilities within overlapping structures of regional and global security governance. The concept of security governance thus highlights the complexities in the policies of the United States and these other states. It points to evidence to show that US imperialist strategy relies to a considerable degree on the cooperation of both state and non-state actors and that its interests and reach may be more specific than frequently suggested in the current debate.

\section{References}

Agnew, John. (2003) American Hegemony into American Empire? Lessons from the Invasion of Iraq. Antipode 35: 871-885.

Axworth, Lloyd. (2001) Human Security and Global Governance: Putting People First. Global Governance 7(1): 19-23.

Bernstein, Richard. (2003) Germany Offers to Expand Afghan Force If the UN Approves. New York Times, August 28.

Black, Ian. (2001) NATO Convinced by"Clear and Compelling" Evidence. Guardian, October 3.

Buzan, Barry, Ole Wæver, and Jaap de Wilde. (1998) Security: A New Framework for Analysis. Boulder, CO: Lynne Rienner.

Bush, George W. (2002) National Security Strategy of the United States of America.

Washington, DC: White House. Available at www.whitehouse.gov/nsc/nss.pdf.

Camm, Frank (1996) Expanding Private Production of Defense Services. Santa Monica: RAND.

Canada Department of National Defense. (2005) Operation ATHENA: The Canadian Forces Participation in ISAF. Available at www.forces.gc.ca/site/operations/Athena/index_e.asp.

Commission on Global Governance. (1995) Our Global Neighbourhood. Oxford: Oxford University Press.

Cooley, Alexander, and James Ron. (2002) The NGO Scramble: Organizational Insecurity and the Political Economy of Transnational Action. International Security 27(1): 5-39.

Cox, Michael. (2002) September $11^{\text {th }}$ and US Hegemony--Or Will the $21^{\text {st }}$ Century Be American Too? International Studies Perspectives 3(1): 53-70.

Croft, Stuart, Elke Krahmann, Jolyon Howorth, Terry Terriff, and Mark Webber. (2004) The Governance of European Security. Review of International Studies 30(1): 3-26.

Cronin, Bruce. (2001) The Paradox of Hegemony: America's Ambiguous Relationship with the United Nations. European Journal of International Relations 7: 103-130.

Czempiel, Ernst-Otto. (1992) Governance and Democratization. In Governance Without Government: Order and Change in World Politics, edited by James N. Rosenau and Ernst Otto Czempiel. Cambridge: Cambridge University Press. 
Dombey, Daniel. (2004) Compromise by NATO Opens Way to Iraq Training Mission. Financial Times, July 31.

Duffield, Michael. (2001) Global Governance and the New Wars. London: Zed Books.

Dumbrell, John (2002) Unilateralism and "America First"? President George W. Bush's Foreign Policy. Political Quarterly 73(3): 279-287.

Finkelstein, Lawrence S. (1995) What Is Global Governance? Global Governance 1(3): 367-372.

Gittings, John. (2001) US Claims China and Russia as Allies. Guardian, October 22.

Gordenker, Leon, and Thomas G. Weiss. (1996) Pluralizing Global Governance: Analytical Approaches and Dimensions. In NGOs, the UN, and Global Governance, edited by Leon Gordenker and Thomas G. Weiss. London: Lynne Rienner.

Gow, James. (1997) Triumph of the Lack of Will: International Diplomacy and the Yugoslav War. London: Hurst.

Graham, Bradley. (2004) Military Spending Sparks Warning. Washington Post, March 8.

Guardian. (2003a) Turkey Delays Vote on US Troops. February 27.

Guardian. (2003b) Turkey Delays US Troop Decision. March 3.

Haass, Richard N. (1999) What to Do with American Primacy. Foreign Affairs 78(5): 37-49.

Hall, Rodney Bruce, and Thomas J. Biersteker, eds. (2002) The Emergence of Private Authority in Global Governance. Cambridge: Cambridge University Press.

Henley, Jon, Nick Paton Walsh, John Gittings, and John Hooper. (2003) Harsh Words from Peace Camp, Muted Praise from Backers. Guardian, March 21.

HIIK. (2003) Konfliktbarometer 2003. Heidelberg: HIIK.

Huntington, Samuel. (1999) The Lonely Superpower. Foreign Affairs 78(2): 35-49.

ICRC. (2001) Annual Report 2001. Geneva: ICRC.

Ikenberry, G. John. (2002) America's Imperial Ambition. Foreign Affairs 81(5): 44-60.

Ikenberry, G. John. (2003) Strategic Reactions to American Preeminence: Great Power Politics in the Age of Unipolarity. Washington, DC: National Intelligence Council. Available at www.cia.gov/nic/confreports_stratreact.html.

Jakobsen, Viggo. (1994) Multilateralism Matters But How? The Impact of Multilateralism on Great Power Policy Towards the Break-up of Yugoslavia. San Domenico: EUI.

Jervis, Robert. (2003) The Compulsive Empire. Foreign Policy 137 (July-August): 83-87.

Kagan, Robert. (1998) The Benevolent Empire. Foreign Policy 111 (Summer): 24-35.

Kaldor, Mary. (2003) American Power: From "Compellance" to Cosmopolitanism? International Affairs 79(1): 1-22.

Koch, Andrew. (2004) U.S. Is Now Set to Turn the Focus on African Security. Jane's Defence Weekly, April 21.

Krahmann, Elke. (2003a) Multilevel Networks in European Foreign Policy. Aldershot: Ashgate.

Krahmann, Elke. (2003b) Conceptualizing Security Governance. Cooperation and Conflict 38(1): 5-26. 
Krahmann, Elke. (2003c) National, Regional, and Global Governance: One Phenomenon or Many? Global Governance 9(3): 323-346.

Krahmann, Elke. (2005) Private Firms and the New Security Governance. Conflict, Security and Development 5(2): 247-268.

Krause, Keith, and Michael C. Williams, eds. (1997) Critical Security Studies: Concepts and Cases. Minneapolis: University of Minnesota Press.

Layne, Christopher. (1993) The Unipolar Illusion: Why New Great Powers Will Rise. International Security 17(4): 5-51.

Manhire, Toby. (2003) West African Press Review. Guardian, August 6.

Markusen, Ann R. (2003) The Case Against Privatizing National Security. Governance 16(4): 471-501.

Mastanduno, Michael. (1997) Preserving the Unipolar Moment: Realist Theories and U.S. Grand Strategy after the Cold War. International Security 21(4): 49-88.

Mearsheimer, John. (1990) Back to the Future: Instability in Europe after the Cold War. International Security 15(1): 5-56.

Merritt, Richard L., and Dina A. Zinnes. (1989) Alternative Indexes of National Power. In Power in World Politics, edited by Richard J. Stoll and Michael D. Ward. Boulder, CO: Lynne Rienner.

Minear, Larry, Ted van Baarda, and Marc Sommers. (2000) NATO and Humanitarian Action in the Kosovo Crisis. Occasional Papers. Providence, RI: Watson Institute.

Murphy, Craig N. (2000) Global Governance: Poorly Done and Poorly Understood. International Affairs 76: 789-803.

NATO. (2004) Statement by the Secretary General of NATO on NATO assistance to Iraq. Press Release, July 30.

NATO. (2005) International Security Assistance Force in Afghanistan. Available at www.afnorth.nato.int/ISAF/structure/structure_structure.htm.

Nau, Henry R. (2002) Does NATO Matter Anymore. The Observer, September 15.

Nye, Joseph S. (2002) The Paradox of American Power: Why the World's Only Superpower Can't Go It Alone. New York: Oxford University Press.

Pint, Ellen M., John R. Bondanella, Jonathan Cave, Rachel Hart, and Donna Keyer. (2001) Public-Private Partnerships. Background Papers for the U.S.- U.K. Conference on Military Installation Assets, Operations, and Services. Santa Monica: RAND.

Posen, Barry R. (2003) Command of the Commons. The Military Foundations of U.S. Hegemony. International Security 28(1): 5-46.

Posen, Barry R., and Andrew L. Ross. (1996/1997) Competing Visions for U.S. Grand Strategy. International Security 21(3): 5-53.

Rhodes, Edward. (2003) The Imperial Logic of Bush's Liberal Agenda. Survival 45(1): 131-154.

Rosenau, James N. (1992) Governance, Order, and Change in World Politics. In Governance without Government: Order and Change in World Politics, edited by James N. Rosenau and Ernst-Otto Czempiel. Cambridge: Cambridge University Press. 
Rosenau, James N., and Ernst-Otto Czempiel, eds. (1992) Governance without Government: Order and Change in World Politics. Cambridge: Cambridge University Press.

Rupert, Mark. (1995) Producing Hegemony: The Politics of Mass Production and American Global Power. Cambridge: Cambridge University Press.

Sciolino, Elaine. (2004) Drifting NATO Finds New Purpose with Afghanistan and Iraq. New York Times, February 23.

Shanker, Tom. (2003) Pentagon Says It May Need to Call Up More Reservists. New York Times, September 25.

Sharrock, David. (2003) £8bn Pledged But Aid to Rebuild Iraq Falls Short of Target. The Times, October 25.

Singer, Peter W. (2003) Corporate Warriors. Ithaca, NY: Cornell University Press.

SIPRI. (2003) SIPRI Yearbook 2003. Oxford: Oxford University Press.

Smith, Helen. (2003) Turkey Opens Airspace But Blocks Airbases. Guardian, March 20.

Spinner, Jackie. (2004) Halliburton to Return \$27.4 Million to Government. Washington Post, February 4.

Thomas, Caroline. (2000) Global Governance, Development, and Human Security. London: Pluto.

Traynor, Ian. (2001) Russia Puts a Brave Face on the Inevitable. Guardian, December 14.

Tuathail, Gearóid Ó, Andrew Herod, and Susan M. Roberts. (1998) Negotiating Unruly Problematics. In An Unruly World? Globalisation, Governance, and Geography, edited by Andrew Herod, Gearoid Ó. Tuathail, and Susan M. Roberts. London: Routledge.

Volgy, Thomas J., and Lawrence E. Imwalle. (1995) Hegemonic and Bipolar Perspectives on the New World Order. American Journal of Political Science 39: 819-834.

Wallace, William/ (2002) American Hegemony: European Dilemmas. Political Quarterly 73(1): 105-118.

Wallerstein, Immanuel. (2002) The Eagle Has Crash Landed. Foreign Policy 131 (July-August): 60-68.

Waltz, Kenneth. (1979) Theory of International Politics. Reading, MA: Addison \& Wesley.

Waltz, Kenneth. (1993) The Emerging Structure of International Politics. International Security 18(2): 45-73.

Weisman, Jonathan, and Anitha Reddy. (2003) Spending On Iraq Sets Off Gold Rush. Washington Post, October 9.

Whitmore, Brian. (2004) U.S. Pushes Antiterror Alliance for North African Nations. Globe, April 11.

Wilkinson, David. (1999) Unipolarity without Hegemony. International Studies Review 1(2): 141-172.

Wohlforth, William C. (1999) The Stability of a Unipolar World. International Security 24(1): 5-41.

Woollacott, Martin. (2003) America Helped Ruin Liberia. Now It Must Help Repair It. Guardian, August 1.

Young, Oran R. (2000) Global Governance: Drawing Insights from the Environmental Experience. Cambridge, MA: MIT Press.

Younge, Gary, Nick Paton Walsh, Jon Henley, and Oliver Burkeman. (2003) Russia and France Angered by End of Diplomacy. Guardian, March 18.

\section{Note: Page breaks correspond to the printed version.}

